\title{
PENGARUH MOTIVASI KERJA, DAN GAYA KEPEMIMPINAN TERHADAP KINERJA KARYAWAN PT. AMDAFA MELANDU MANDIRI KECAMATAN LUBUK KILANGAN KOTA PADANG
}

\author{
Muhammad Mahzum \\ Universitas Putra Indonesia YPTK Padang \\ mahzum.mhd@gmail.com
}

\begin{abstract}
This study aims to reveal, (1). The Influence of Intrinsic Motivation on Employee Performance, (2) Effect of Extrinsic Motivation on Employee Performance (3) Effect of Internationalized Employee Leadership Style on Employee Performance (4) Effect of anorizing Leadership Style Assignment on Employee Performance (5) Effect of Intrinsic \& Extrinsic Motivation, Internative Style Employees \& Tasks together on Employee Performance. The population in this study were employees of PT. Amdafa Guides Mandiri in Lubuk Kilangan Subdistrict, Padang City, amounting to 49 people. Sampling using Slovin formula and cluster random sampling method obtained a sample of 45 people. The method used in this research is simple random sampling method. The results of the study indicate that the variable Work Motivation and Leadership Style partially and simultaneously significantly influence Employee Performance
\end{abstract}

Keywords: Work Motivation, Leadership Style and Employee Performance

\begin{abstract}
ABSTRAK
Penelitian ini bertujuan untuk mengungkap, (1). Pengaruh Motivasi Intrinsik terhadap Kinerja Karyawan, (2)Pengaruh Motivasi Ekstrinsik terhadap Kinerja Karyawan (3) Pengaruh Gaya Kepemimpinan beroreantasi Karyawan terhadap Kinerja Karyawan (4) Pengaruh Gaya Kepemimpinan beroreantasi Tugas terhadap Kinerja Karyawan (5) Pengaruh Motivasi Intrinsik \& Ekstrinsik, Gaya Kepemimpinan Beroreantasi Karyawan \& Tugas secara bersama-sama terhadap Kinerja Karyawan. Populasi dalam Penelitian ini adalah Karyawan PT. Amdafa Melandu Mandiri Kecamatan Lubuk Kilangan Kota Padang yang berjumlah 49 orang. Pengambilan sampel dengan menggunakan formula Slovin dan metoda cluster random sampling diperoleh sampel sebanyak 45 orang. Metode yang digunakan dalam penelitian ini adalah metode simple random sampling. Hasil dari penelitian menunjukkan bahwa variabel Motivasi Kerja dan Gaya Kepemimpinan secara parsial dan simultan berpengaruh secara signifikan terhadap Kinerja Karyawan
\end{abstract}

Kata kunci: Motivasi Kerja, Gaya Kepemimpinan dan Kinerja Karyawan

\section{Pendahuluan}

Globalisasi, liberalisme perdagangan, deregulasi dan kemajuan teknologi informasi menciptakan realitas baru persaingan yang kian ketat. Globalisasi telah mengubah segala sesuatu yang membatasi menjadi lepas tak terbendung. Setiap perusahaan akan dengan mudah memperoleh sumber daya yang diinginkan kapan dan dimanapun sumber daya tersebut tersedia.

Manajemen Sumber Daya Manusia merupakan fungsi yang sangat penting dalam organisasi, yang menduduki posisi sebagai partner bagi keseluruhan strategi bisnis. MSDM meletakkan peran SDM sebagai kunci sukses organisasi dalam mencapai tujuannya.

Tampak saat ini diupayakan penerapan paradigma dan system MSDM yang lebih berorientasi pada peningkatan kepuasan, ketentraman, kegairahan dan hasil kerja pada karyawan (Reksohadiprojo dan Handoko, 2000)

Perusahaan swasta, dalam hal ini PT. Amdafa Melandu Mandiri dalam melaksanakan aktifitasnya atau melakukan giatan usaha dibidang Kontraktor dalam hal ini Konstruksi Mesin / Baja, Sipil, Bengkel Fabrikasi dan Perdagangan. 
Manajemen perusahaan PT. Amdafa Melandu Mandiri bertanggung jawab terhadap kelancaran operasional perusahaan, melakukan pendekatan dan negosiasi dengan pihak lain untuk mendapatkan order atau pekerjaan, sehingga target yang ditetapkan dapat tercapai. Pada saat ini kinerja karyawan menginformasikaun gejala-gejala yang kurang menggembirakan, masih ada karyawan yang kurang memiliki motivasi untuk bekerja, disiplin yang kurang sehingga sering terlambat masuk jam karja dan kurangnya gairah dalam melaksanakan pekerjaan sehari-hari. Hal ini bila dibiarkan akan perpengaruh negatif terhadap kinerja perusahaan.

Sesuai dengan uraian tersebut diatas jelas bahwa motivasi kerja dan semangat kompetitif para karyawan semakin rendah, sikap apatis para karyawan nampak terlihat, kondisi ini sesuai dengan persepsi bahwa karyawan bekerja secara santai dan dan karyawan yang bekerja maksimal merasa diperlakukan secara sama oleh pimpinan / manajemen. Kondisi seperti ini jelas berpengaruh negatif terhadap kinerja karyawan sekaligus juga berpengaruh terhadap keuntungan / profit yang akan dicapai.

\section{Tinjauan Literatur}

\section{1. Kenerja}

Setiap karyawan dituntut untuk bekerja optimal, baik secara kuantitas maupun secara kualitas, sehingga perusahaan berpotensik untuk merebut puluang pasar. Secara keseluruhan, produktivitas karyawan merupakan kinerja karyawan. Untuk mengetahui kinerja, maka perlu adanya sarana penilai prestasi kerja.

Performance diterjemahkan menjadi kinerja, juga berarti prestasi kerja, pencapaian kerja atau hasil kerja / unjuk kerja / penampilan kerja (L.A.N, 1982). (August W. Smith 1982) menyatakan bahwa performance atau kinerja adalah : "Output drive from process, human or otherwise", menurutnya bahwa kinerja merupakan hasil atau keluaran dari suatu proses.

Kinerja mempunyai hubungan erat dengan masalah produktifitas karena merupakan indikator dalam menentukan bagaimana usaha untuk mencapai tingkat produktifitas yang tinggi dalam suatu organisasi. Berkenaan hal tersebut maka upaya untuk mengadakan penilaian terhadap kinerja disuatu organisasi merupakan hal penting.

L.R. Sayle dan Strauss (1977) mengutarakan bahwa : "manager expected to be held to standart of accountability, and most managers pfrefer to have their establisehed unambiguously, so they know where to carry out their energies. In effect, the standart established a target, and at the end of the target periode (week, month, or year) both manager and boss can compare the expected standart of performance with the actual level off achievement.

Ungkapan tersebut diatas dinyatakan bahwa standar kinerja perlu dirumuskan guna menjadikan tolok ukur dalam mengadakan terbandingan antara apa yang telah dilakukan dengan apa yang diharapkan, kaitannya dengan pekerjaa atau jabatan yang telah dipercayakan kepada seseorang. Standart dimaksud dapat pula dijadikan sebagai ukuran dalam mengadakan pertanggung jawaban terhadap apa yang telah dilakukan.

Dalam bukunya personnel, The Managemen of Human Resource, R.Wayne \& Robert Noe mendefinisikan manajement SDM sebagai berikut : "Human Resource Management is the itilization of the firm's human assets to achieve organization objectives". Manajemen sumber daya manusia adalah pengelolaan / pemanfaatan aset manusia untuk mencapai tujuan organisasi.

Secara spesifik tujuan manajemen sumber daya manusia sebuah organisasi adalah mengelola dan atau mengembangkan kompetensi personil agar mampu merealisasikan misi organisasi. Konsep ini dikenal sebagai Competency Based Human Resource Management, dapat dikatakan bahwa semua aktifitas manajemen sumber daya manusia berorientasi pada pengembangan dan pemanfaatan kompetensi karyawan. Misalnya proses penilaian kinerja berdasarkan kompetensi, pelatihan berorientasi pada kompetensi, rekrutmen berdasarkan kompetensi.

T. Hani Handoko dalam bukunya Manajemen Personalia dan Sumber Daya Manusia juga mengemukakan bahwa "Penilaian Prestasi adalah proses melalui mana organisasi-organisasi mengevaluasi atau menilai prestasi kerja karyawan. Kegiatan ini dapat memperbaiki keputusankeputusan personalia dan memberikan umpan balik pada karyawan tentang pelaksanaan kerjan mereka. 
Menurut Schererhon, Hunt dan Osom (1998), kinerja adalah kuantitas dan kualitas pencapaian tugas, baik yang dilakukan individu, kelompok maupun organisasi. Aspek kuantitas mengacu pada beban kerja/target, sedangkan kualitas menyangkut kerapihan dan kesempurnaan pekerjaan yang sudah dilaksanakan.

Sementara itu Hadari Nawawi (2003, Hand Out "Evaluasi Kinerja untuk mengembangkan prestasi para pekerja yang potensial"), menyatakan bahwa prestasi kerja itu merupakan gabungan dari tiga factor terdiri dari : (a) minat dalam bekerja, (b) penerimaan delegasi tugas, serta (c) peran dan tingkat motivasi seseorang pekerja. Semakin tinggi factor-faktor tersebut maka makin besar prestasi kerja atau kinerjanya.

Menurut Judith R. Gordon (1998), kinerja adalah salah satu fungsi kemampuan pekerjaan dalam menerima tujuan pekerjaan, tingkat pencapaian tujuan dan interaksi antara tujuan dan kemampuan pekerjaan. Sedangkan menurut Suyadi Prawirosentono (1998), kinerja adalah hasil kerja yang dicapai seseorang atau kelompok orang dalam suatu organisasi perusahaan, sesuai dengan wewenang dan tanggung jawab masing-masing, dalam rangka upaya mencapai tujuan organisasi secara legal, tidak melanggar hokum dan sesuai dengan moral dan etika.

\subsection{Motivasi Kerja}

Setiap organisasi akan berusaha mencapai target yang telah ditetapkan, salah satu usaha yang dilakukan adalah dengan memberikan motivasi yang tinggi kepada tenaga kerjanya. Menurut G.R. Terry $(2000,130)$ motivasi dapat diartikan sebagai mengusahakan supaya seseorang dapat menyelesaikan pekerjaan dengan semangat karena ia ingin melaksanakannya.

Sedangkan Bernard Berelson Gerry A. Stenier mendefinisikan motivasi sebagai keadaan kejiwaan dan sikap mental manusia yang memberikan energi, mendorong kegiatan atau gerakan dan mengarahkan atau menyalurkan perilaku kearah mencapai kebutuhan yang memberi kepuasan atau mengurangi ketidakseimbangan.

Sedangkan Miftah Thoha $(2000,177)$ medefinisikan motivasi sebagai suatu proses psikologi yang merupakan salah satu unsur pokok dalam perilaku seseorang. Sementara itu menurut G.R. Therry $(2000,130)$, motivasi dapat diartikan sebagai mengusahakan supaya seseorang dapat menyelesaikan pekerjaan dengan semangat karena ia ingin melaksanakannya. Tugas manajer ialah menciptakan kondisi-kondisi kerja yang akan membangkitkan dan mempertahankan keinginan untuk bersemangat melalui pemberian motivasi.

Panji Anoraga (2001:35) mengemukan bahwa motivasi adalah sesuatu yang menimbulkan semangat atau dorongan kerja, berupa suatu metode yang mampu menggerakkan seseorang untuk melaksanakan pekerjaannya dengan maksimal dan menjadikan pekerjaan itu menjadi suatu hal yang menyenangkan. Definisi ini menjelaskan bahwa motivasi disebut sebagai pendorong semangat. Kuat dan lemahnya motivasi seseorang dalam bekerja ikut menentukan besar kecil prestasinya.

Barry Cushway dalam Sularno Tjiptowardojo (1999:2) mengemukakan bahwa motivasi berkaitan dengan dorongan yang mempengaruhi perilaku setiap orang di dalam organisasi dan tingkat komitmen yang ditunjukkan oleh para karyawan terhadap pencapaian sasaran dan tujuan organisasi.

Berkaitan dengan motivasi kerja Vroom dalam Asnawi (2002:66-67) menyarankan teori motivasi kerja yang dikenal dengan singkatan VIE yaitu Valensi / kemampuan (Valence), sarana (Instrumentality) dan harapan (Expectancy). Valence mangacu kepada keinginan dan kemampuan yang menarik atau menolak dan memiliki sesuatu tertentu pada lingkungan kerja. Uang misalnya memiliki valence positif bagi kebanyakan orang, sementara kondisi kerja yang tidak aman memiliki valence negative. Sarana : bagaimana kemungkinannya suatu hal yang potensial akan berimplikasi terhadapl sesuatu yang bernilai lain, misalnya kinerja yang baik berimplikasi pada promosi atau kanaikkan jabatan. Sarana didasarkan pada konsep path-goal, yang merupakan hubungan yang dirasakan antara dua hasil. Expectancy : bagaimana mungkin pekerja meyakini bahwa apa yang telah diusahakan itu akan membawa kepada kinerja yang baik. 
Dari beberapa pengertian motivasi yang dikemukakan tersebut, dapat disimpulkan bahwa motivasi adalah sebagai faktor pendorong baik yang bersifat internal maupun yang bersifat eksternal untuk mencapai tujuan, baik yang bersifat individual maupun kelompok dalam suatu organisasi

\subsection{Gaya Kepemimpinan.}

Kepemimpinan diartikan sebagai kemampuan mengarahkan pengikut-pengikut untuk bekerja bersama dengan kepercayaan, serta tekun dalam mengerjakan tugas-tugas yang diberikan oleh pemimpin mereka. Sebaliknya pemimpin berkonsentrasi pada fungsi-fungsi yang berorientasi pada tugas penting seperti merencanakan dan mengatur pekerjaan, mengkoordinasikan kegiatan bawahan dalam menetapkan tujuan-tujuan kinerja (performance goods) yang tinggi tapi realistis.

Wishboard dalam bukunya "Organization Diagnosisi : A Work Book of Theory Practice : seperti yang dikutip oleh Agus Dharma dalam bukunya "Gaya kepemimpinan yang efektif bagi para manajer, yaitu gaya kepemimpinan lahir akibat pemahaman atas masalah kepemimpinan yang selanjutnya dikembangkan dengan mengkombinasikan tinjauan sosiologi dengan pendekatan psikologi.

Terdapat 4 (empat) macam Pola Umum Gaya Kempemimpinan yaitu :

\section{a. Otoriter}

Ciri-ciri perilaku kepemimpinan otoriter :

1. Semua perilaku kebijaksanaan ditentukan oleh pimpinan

2. Langkah-langkah teknis ditentukan oleh pimpinan pada saat-saat tertentu, sehingga biasanya langkah berikutnya tidak ada kepastian.

3. Pimpinan mendiktekan tugas-tugas tertentu dan para anggota adalah pelaksananya.

4. Pimpinan cenderung untuk mencela atau memuji secara personal dan tetap menjauhkan diri dari kegiatan kelompok, kecuali dalam berdemonstrasi.

\section{b. Paternalistik}

Ciri-ciri kepemimpinan paternalistik :

1. Dia menganggap bawahannya sebagai manusia yang tidak / belum dewasa, atau anak sendiri yang perlu dikembagkan.

2. Terlalu bersifat melindungi.

3. Jarang memberikan kesempatan pada bawahannya untuk mengambil keputusan sendiri.

4. Selalu bersikap maha tahu dan maha benar.

c. Laissez Faire

Ciri-ciri kepemimpinan Laissez Faire :

1. Kebebasan sepenuhnya untuk mengambil keputusan, diberikan kepada kelompok manapun individual tanpa banyaknya campur tangan pimpinan.

2. Bermacam-macam bahan atau data diberikan. Pimpinan dengan jelas menyatakan hanya akan memberikan bahan informasi bila diminta saja. Pimpinan tidak mengambil keaktifan dalam pembahasan bersama kelompok.

3. Sama sekali tidak berpartisipasi serta kurang becus menjadi pimpinan.

4. Jarang memberikan komentar secara spontan terhadap kegiatan bawahannya, kecuali bila ditanya. Tidak ada usaha-usaha untuk menilai atau mengatur jalannya pekerjaan organisasi.

d. Demokratik

Ciri-ciri kepemimpinan demokratik :

1. Semua kebijaksanaan dibahas dan ditentukan bersama-sama kelompok, dengan dorongan dan bantuan pimpinan.

2. Perspektif kegiatan diperoleh selama masa pembahasan, langkah-langkah umum kebijaksanaan kelompok digariskan terlebih dahulu dan jika diperlukan dapat meminta nasehat teknis. Pimpinan memberikan saran beberapa alternatif prosedur yang dapat dipilih.

3. Para pegawai bawahan bebas untuk bekerjasama dengan siapa saja yang mereka senangi. Pembagian tugas pekerjaan diserahkan kepada kelompok untuk ditentukan bersama.

4. Pimpinan selalu "objektif dan berfikir serba fakta" dalam memberikan semangat kepada kelompok, tanpa banyak mencampuri urusan pekerjaan. 
Beberapa gaya kepemimpinan atau style kepemimpinan yang banyak mempengaruhi keberhasilan seorang pimpinan dalam mempengaruhi perilaku bawahan / pengikut-pengikutnya. Jika seseorang dalam posisi sebagai pimpinan di dalam sebuah organisasi / perusahaan, dan menginginkan pengembangan staf dan membangun iklim motivasi untuk menghasilkan tingkat produktifitas yang tinggi, maka yang bersangkutan harus memikirkan gaya kepemimpinannya.

Gaya kepemimpinan merupakan norma perilaku yang digunakan oleh seseorang pada saat orang tersebut mencoba mempengaruhi perilaku orang lain seperti yang ia lihat. Beberapa ahli mengemukakan gaya kepemimpinan seperti berikut :

Gaya kepemimpinan menurut Miftah Thoha (2000;265), mengindentifikasikan dua ketegori gaya yang ekstrim, yakni : gaya kepemimpinan otokratis, dan gaya demokratis, kempemimpinan dan penggunaan otoritas. Sementara itu gaya kepemimpinan demokratis dikaitkan dengan kekuatan personal dan keikutsertaan para pengikut dalam proses pemecahan masalah dan pengambilan keputusan.

Dari pengertian yang dikemukakan diatas, dapat dikatakan bahwa gaya kepemimpinan otokratis dan demokratis, keduanya merupakan gaya kepemimpinan, dan oleh karenanya dapat didudukkan dalam suatu kontinum dari perilaku pimpinan yang sangat otokratis pada suatu ujung sampai kepada perilaku pemimpin yang sangat demokratik pada ujung lain.

Gaya kepemimpinan yang dikemukakan oleh Hersy \& Kenneth H. Blanchard adalah gaya kepemimpinan bersifat situasional dibagi atas 4 (empat) tipe, seperti berikut :

- Instruktif

- Konsultatif

- Partisipatif

- Delegatif

Keempat gaya kepemimpinan tersebut di dalam pelaksanaannya disesuaikan dengan situasi dan kondisi bawahan, sehingga diharapkan bahwa pelaksanaan tugas dan pekerjaan dapat terlaksana dengan baik.

Berdasarkan telaah pustaka yang telah dilakukan diatas, maka model pemikiran teoritis yang dikembangkan pada penilitian ini terlihat pada gambar berikut ini :

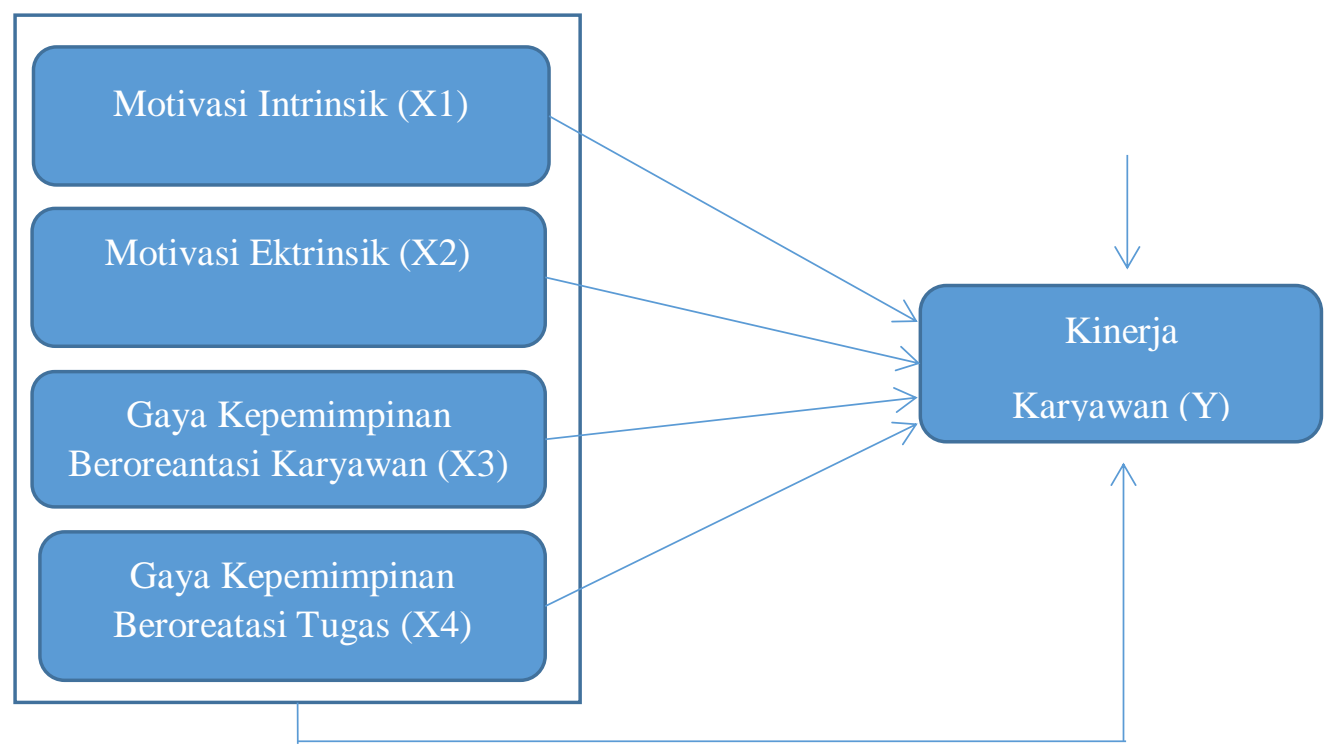

\section{Metodologi}

Gambar 2.1 : Kerangka Konseptual

Metode penelitian yang digunakan dalam penelitian ini adalah motode survei. Metode Survei menurut Sugiono (2009) adalah penelitian yang dilakukan pada populasi besar maupun kecil, tetapi 
data yang diperlajari adalah data dari sampel yang diambil dari populasi tersebut, sehingga dapat ditemukan kejadian-kejadian relatif, distributif dan hubungan antar variabel, sosiologis mupun psikologis. Sedangkan bentuk penelitiannya adalah Penelitian Deskiriptif. Penelitian Deskriptif adalah mempelajari masalah-masalah deskriptif dalam masyarakat, serta tata cara yang berlaku dalam masyarakat serta situasi-situasi tertentu, termasuk tentang hubungan kegiatan-kegiatan, sikapsikap, pandangan, serta proses-proses yang sedang berlangsung dan pengaruh-pengaruh dari fenomena. Dalam penelitian ini, metodedeskriptif tertujuan mengungkap atau menjelaskan karakteristik dari masing-masing variabel dengan variabel lainnya (secara parsial dan simultan) namun belum dijelaskan karakteristrik dari variabel itu apakah Motivasi Instrinsik, Motivasi Ekstrinsik, Gaya Kepemimpinan Berorentasi Karyawan dan Gaya Kepemimpinan Berorentasi Tugas pada objek yang diteliti belum terlaksana dan berjalan dengan baik, hal ini dijelaskan melalui penelitian deskriptif.

Dalam hal teknik pengumpulan data menurut kegiatan yang dilakukan maka teknik yang digunakan adalah Survei Lapangan (field survei). Survei lapangan dilakukan dengan cara mengisi kuisioner oleh karyawan PT. Amadafa Melandu Mandiri. Kuisioner yang diberikan adalah kuisioner yang telah ditentukan jawabannya, responden hanya memilih satu dari beberapa jawaban yang ada. Metodologi yang diterapkan dalam melaksanakan penelitian harus dijelaskan dengan baik.

\section{Teknis Analisis dan Uji Hipotesa}

Teknik analisis data dalam penelitian ini menggunakan regresi berganda, yaitu suatu pendekatan yang bertujuan untuk melihat sejauh mana kemampuan dari semua variabe bebas atau independen yang meliputi motivasi instrinsik (X1), motivasi ekstrinsik (X2), gaya kepemimpinan beroreantasi karyawan (X3) dan gaya kepemimpinan berorentasi tugas (X4) dalam menjelaskan dan mempengaruhi variabel terikat atau dependen dalam hal ini adalah variabel kinerja karyawan (Y). Namun sebelum dilakukan analisis regresi linear berganda, telah dilakukan pengujian persyaratan atau asumsi klasik yang meliputi uji normalitas, mutikolinearitas, dan heteroskedastisitas. Dimana secara keseluruhan temuan menunjukkan model yang dibangun dapat memenuhi model yang layak atau dapat menjelaskan kerangka konseptual yang telah dibentuk dalam menjelaskan hipetesis penelitian.

Berikut ringkasan hasil pengujian regresi linear berganda, sebagaimana yang tersaji pada tabel dibawah ini :

Tabel 1. Hasil Nilai Koefisien Regresi

\begin{tabular}{|c|c|c|c|}
\hline $\begin{array}{l}\text { Varibel } \\
\text { Terikat }\end{array}$ & Variabel Bebas & Beta & Signifikan \\
\hline \multirow{8}{*}{$\begin{array}{c}\text { Kinerja } \\
\text { Karyawan (Y) }\end{array}$} & Motivasi Intrinsik (X1) & 0,087 & 0,259 \\
\hline & Motivasi Ekstrinsik (X2) & 0,100 & 0,032 \\
\hline & $\begin{array}{l}\text { Gaya Kepemimpinan Berorientasi } \\
\text { Karyawan (X3) }\end{array}$ & 0,071 & 0,195 \\
\hline & $\begin{array}{l}\text { Gaya Kepemimpinan Berorientasi } \\
\text { Tugas (X4) }\end{array}$ & 0,362 & 0,000 \\
\hline & Konstanta (a) & 2,990 & 0,000 \\
\hline & $\mathrm{F}$ & 7,660 & 0,000 \\
\hline & $\mathrm{R}$ & \multicolumn{2}{|c|}{0,659} \\
\hline & R2 & \multicolumn{2}{|c|}{0,434} \\
\hline
\end{tabular}

Sumber : Hasil Pengolahan Data SPSS 17 


\section{Hasil dan Diskusi}

\subsection{Pengaruh Motivasi Instrinsik Terhadap Kinerja Karyawan.}

Berdasarkan hasil rekresi linear berganda pada tabel 1 diatas, ditemukan nilai koefisien regresi motivasi instrinsik sebesar 0,087 dengan nilai signifikan sebesar 0,259 yang jika dibandingkan dengan kesalahan menolak data sebesar 0,05, nilai ini sangat tinggi. Dengan demikian dapat disimpulkan bahwa tidak ada pengaruh motivasi intrinsik terhadap kinerja karyawan PT. Amdafa Melandu Mandiri. Hasil temuan ini didasarkan atas kondisi dan realita yang ada bahwa karyawan yang diteliti atau sampel yang diperoleh 45 orang, sebayak 44 karyawan adalah berpendidikan SMA, SMP dan ada yang tamatan SD. Artinya sumber daya manusianya sangat rendah sekali. Bahwa dorongan dari dalam diri karyawan itu untuk lebih berkembang dan maju sangatlah rendah sekali yang demikian terjadi berbanding lurus dengan tingkat pendidikan yang rendah.

Menurut Shanker dan Barton (1996) Motivasi Intrinsik adalah berupa dorongan dari dalam diri karyawan untuk melakukan sesuatu dalam rangka melaksanakan tugas dan kewajiban di tempat kerja.

\subsection{Pengaruh Motivasi Ekstrinsik Terhadap Kinerja Karyawan.}

Sesuai dengan hasil regresi linear berganda sebagaimana data yang ada di tabel diatas, juga menghasilkan nilai koefisien regresi motivasi ekstrinsik sebesar 0,100 dengan nilai signifikan sebesar 0,032 yang jika dibandingkan dengan kesalahan menolak data 0,05 nilai ini relatif rendah. Dengan demikian dapat disimpulkan bahwa terdapat pengaruh positif yang signifikan Motivasi Ekstrinsik terhadap Kinerja Karyawan PT. Amdafa Melandu Mandiri Kecamatan Lubuk Kilangan Kota Padang. Sementara bentuk hubungan dan pengaruh kedua variabel juga terlihat masih berslop positif. Hubungan ini juga dapat dimaknai, dimana jika semakin tinggi tingkat Motivasi khususnya motivasi Ekstrinsik yang diberikan oleh organisasi atau perusahaan kepada karyawannya dalam mendukung dan menyelesaikan pekerjaannya, maka hal ini akan dapat berdampak semakin tinggi kinerja yang dihasilkan oleh karyawan dimaksud. Namun jika semakin rendah motivasi ekstrinsik diberikan, maka hal ini juga semakin rendahnya kinerja yang akan dihasilkan karyawan dalam bekerja.

Temuan Hipotesis ini juga didukung oleh landasan teori yang dinyatakan oleh Oliver Richard \& Erin Anderson (1994) bahwa motivasi ekstrinsik merupakan dorongan yang berasal dari luar diri karyawan untuk melakukan sesuatu. Artinya jika seorang karyawan jika dimotivasi dengan sesuatu yang berasal dari luar dirinya berupa harapan-harapan, janji-janji yang motivasi itu bertoreantasi kepada penambahan kesejahteraan misalnya, maka karyawan ini sungguh bersemangat dalam melaksanakan perkerjaan dan guna meningkatkan kinerjanya di dalam organisasi atau perusahaan.

\subsection{Pengaruh Gaya Kepemimpinan Berorentasi KaryawanTerhadap Kinerja}

Dari hasil regresi linear berganda pada tabel 1, terlihat nilai koefisien regresi Gaya Kepemimpinan beroreantasi Karyawan sebesar 0,071 dengan nilai signifikan sebesar 0,195. Nilai signifikan ini terlihat lebih tinggi dari nilai kesalahan menolak data sebesar 0,05 atau 0,195>0,05. Oleh karena itu dapat disimpulkan bahwa tidak ditemukan pengaruh yang positif dan signifikan Gaya Kepemimpinan yang beroreantasi Karyawan. Hal ini dapat disebabkan oleh karena karyawan PT. Amdafa Melandu Mandiri rata-rata berpendidikan rendah dan ditambah dengan keinginan dari dalam diri karyawan untuk lebih berkembang sangat kurang, artinya bahwa mayoritas karyawan tidak memiliki keinginan untuk mengembangkan diri sebagaimana konsentrasi penelitian yang menekan kepada gaya kepemimpinan beroreantasi karyawan. 
Sesuai dengan apa yang disampaikan oleh para ahli yang bernama Yeh dan Quey-Jen (1996) bahwa Gaya Kepemimpinan beroreantasi karyawan adalah implementasi kepemimpinan yang menekankan pada pengembangan karyawan. Karyawan diberi kesempatan untuk lebih giat dan tekun untuk mengembangkan dirinya dalam melaksanakan dan menjalankan tugas, sehingga diharapkan akan meningkatkan prestasi dan kinerja karyawan dimaksud.

\subsection{Pengaruh Gaya Kepemimpinan Berorentasi Tugas Terhadap Kinerja.}

Menurut hasil regresi linear berganda sebagaimana data yang ada di tabel diatas, juga menghasilkan nilai koefisien regresi gaya kepemimpinan beroreantasi tugas dengan nilai sebesar 0,362 dengan nilai signifikan sebesar 0,000 yang jika dibandingkan dengan kesalahan menolak data 0,05 atau $0,000<0,05$.nilai ini relatif sangat rendah. Dengan demikian dapat disimpulkan bahwa terdapat pengaruh positif yang signifikan Gaya Kepemimpinan Beroreantasi Tugas terhadap Kinerja Karyawan PT. Amdafa Melandu Mandiri Kecamatan Lubuk Kilangan Kota Padang. Sementara bentuk hubungan dan pengaruh kedua variabel juga terlihat masih berslop positif. Hubungan ini juga dapat dimaknai, dimana jika semakin difokuskan atau ditekankan Gaya Kepemimpinan yang berorientasi Tugas artinya kepemimpinan yang memberikan kepercayaan penuh kepada karyawan untuk menyelesaikan tugas dan pekerjaan sesuai dengan fungsi, tugas dan keahliannya, maka pekerjaan itu akan bisa diselesaikan dengan baik, maka hal ini akan dapat berdampak semakin tinggi kinerja yang dihasilkan oleh karyawan dimaksud.

Temuan hipotesis ini didukung oleh kajian tiori yang dijelaskan oleh Yeh dan Quey-Jen (1996) Gaya Kepemimpinan yang berorientasi tugas adalah Implementasi kepemimpinan yang menekankan pada penyelesaian tugas, artinya jika seorang karyawan dapat melaksanakan dan menyelesaikan tugasnya dengan baik maka seorang pemimpin harus memberikan penilaian yang baik sehingga memberikan kepercayaan diri dan berimplikasi terhadap semangat yang tinggi yang berdampak kepada meningkatkannya kinerja karyawan dimaksud di dalam perusahaan.

\subsection{Pengaruh Motivasi dan Gaya Kepemimpinan secara Simultan Terhadap Kinerja Karyawan.}

Penilaian pengaruh secara bersama-sama atau simultan dari semua variabel independen yang meliputi motivasi intrinsik \& ekstrinsik, gaya kepemimpinan berorientasi Karyawan dan gaya kepemimpinan berorientasi tugas terhadap kinerja karyawan PT. Amdafa Melandu Mandiri Kecamatan Lubuk Kilangan Kota Padang dapat dinilai melalui nilai F dan signifikannya. Dimana nilai $F$ adalah sebesar 7,660 dengan nilai signifikan 0,000 . Nilai signifikan yang diperoleh ini jika dibandingkan dengan alpha atau kesalahan menolak data sebesar 0,05 jauh lebih rendah atau 0,000 $<0,05$. Hal ini dapat diartikan terdapat pengaruh motivasi intrinsik \& ekstrinsik serta gaya kepemimpinan berorentasi karyawan \& tugas secara simultan atau secara bersama-sama terhadap kinerja karyawan. Demikian hasil ini juga sejalan dengan temuan atau pengaruh secara parsial dari masing-masing variabel independen yang terutama motivasi ekstrinsik dan gaya kepemimpinan berorientasi tugas terhadap kinerja karyawan. Dengan kata lain variabel-variabel penelitian ini adalah factor yang dapat menentukan dan mempengaruhi naik turunnya kinerja karyawan pada PT. Amdafa Melandu Mandiri Kecamatan Lubuk Kilangan Kota Padang. Oleh karena itu jika organisasi atau perusasahaan berupaya untuk meningkatkan kinerja karyawannya, maka yang harus dilakukan manajemen adalah memperbaiki keempat variabel tersebut diatas.

Selanjutnya bila dilihat dari nilai koefisien determinasi yaitu $\mathrm{R} 2=0,434$, ini berarti bahwa Motivasi intrinsik (X1), Motivasi ekstrinsik (X2), Gaya kepemimpinan berorientasi karyawan (X3) dan Gaya kepemimpinan berorientasi tugas (X4) dengan kinerja karyawan PT. Amdafa Melandu Mandiri adalah sebesar $43,40 \%$, atau terdapat konstribusi variabel selain motivasi kerja dan gaya kepemimpinan dengan kinerja Karyawan sebesar 56,60\% yang tidak diteliti dalam kesempatan ini. 
Anda dapat memasukan hasil dan catatan diskusi. Hasilnya disajikan dalam format yang dapat diakses oleh pembaca (misalnya dalam grafik, tabel, diagram atau teks tertulis). Perhatikan bahwa data mentah biasanya dimasukkan dalam lampiran.

\section{Kesimpulan}

Berdasarkan hasil penelitian yang diuraikan pada bab sebelumnya maka dapat disimpulkan beberapa hal penting dalam penelitian ini yaitu :

a. Terdapat pengaruh positif dan signifikan berupa motivasi kerja terutama motivasi ekstrinsik terhadap Kinerja Karyawan PT. Amdafa Melandu Mandiri Kecamatan Lubuk Kilangan Kota Padang.

b.Terdapat pengaruh positif dan signifikan berupa gaya kepemimpinan khusnya gaya kepemimpinan berorientasi tugas terhadap Kinerja Karyawan PT. Amdafa Melandu Mandiri Kecamatan Lubuk Kilangan Kota Padang.

c. Terdapat pengaruh secara bersama-sama atau simultan motivasi intrinsik \& ekstrinsik, gaya kepemimpinan berorientasi karyawan dan tugas terhadap kinerja karyawan PT. Amdafa Melandu Mandiri Kecamatan Lubuk Kilangan Kota Padang.

d. Dari keempat variabel independen yang ada, ternyata variabel gaya kepemimpinanberorientasi tugas adalah variabel yang paling menentukan kinerja

karyawan PT. Amdafa Melandu Mandiri Kecamatan Lubuk Kilangan Kota Padang.

\section{Referensi}

[1] Alwi Syafaruddin, M.S, 2001. Manajemen Sumber Daya ManusiaYogyakarta : FE UGM.

[2] Atmasoeprapto, Kisdarto, 2002. Menuju SDM Berdaya Dengan Kepemimpinan Efektif dan ManajemenEfisienl. Jakarta:PT.MediaElex Komputindo.

[3] Agus Dharma, 2000. Manajemen Supervisi,Jakarta Raja Grafindo Persada.

[4] Buchari Zainun,1994. Manajemen dan Motivasi, Edisi Revisi. Jakarta : Balai Aksara

[5] Buchari Zainun, 2001 Manajemen Sumber Daya Manusia. Jakarta: Toko Gunung Agung

[6] Diana Anastasia \& Tjiptono Fandy, 2002. Total Quality Manajement Edisi Revisi. Yogyakarta : Andi

[7] Dimock Stuart \& Attwood Margaret, 1999. Manajemen Personalia (terjemahan) Bandung: ITB

[8] Edwin B. Flippo / Moh. Masud, 1994. Manajemen Personalia. Jakarta : Erlangga

[9] Feldman, GD. And Arnold, 1983. Managing Individual and Group Bahavior in Organization. Tokyo: Mc. Graw-Hill

[10] Gomes, Cardoso, Faustino, 2002. Manajemen Sumber Daya Manuasia.Yogyakarta : Andi

[11] Hadari Nawawi, 2003. Manajemen Sumber Daya Manusia untuk Bisnis Yang kompetitif. Gajah Mada University Press

[12] Hasibuan S.P.Malayu, H. 2002. Manajemen Sumber Daya Manusia Edisi Revisi. Jakarta : Bumi Aksara.

[13] Masngudi, Prof. Dr. H. SE.APU, 2003. Metode Penelitian Untuk Ekonomi, Edisi kelima. Jakarta : Fakultas Ekonomi. Universitas Borobudur.

[14] Miftah Thoha, 1997. Pembinaan Organisasi Proses Diagnosa dan Intervensi. Jakarta : Raja Gravindo

[15] Prasetya Irawan, 1999. Logika dan Prosedur Penelitian. Jakarta:STIA LAN

[16] Simanjuntak, Payaman J. 1985 Pengantar Ekonomi Sumber Daya Manuasia. Jakarta . LPFE-UI

[17] Saydam, Gauzali,1996. Manajemen Sumber Daya Manusia. Jakarta : Gunung Agung

[18] Simamora H, 2004. Manajemen Sumber Daya Manusia. Yogyakarta STIE YPKN

[19] Supranto, John,1986. Hubungan Industrial. Yogyakarta : UGM

[20] Supranto, John,2003. Metode Riset Aplikasinya Dalam Pemasaran. Jakarta : Rineka Cipta

[21] Siagian, S. Sondang,2002. Manajemen Sumber Daya Manusia. Jakarta : Bumi Aksara.

[22] Sasro, Hadiwiryo, Siswanto, 2003. Manajemen Tenaga Kerja di Indonesia.Jakarta : Bumi Aksara.

[23] Sedarmayanti,1995.Sumber Daya Manusia dan Produktivitas Kerja. Bandung: Ilham Jaya.

[24] Tordi, Ahmad, 2002. Pemahaman Praktis Manajemen Sumber Daya Manusia. Bandung : Mandar Maju

[25] Timpee, A, 2000. Seri Manajemen Sumber Daya Manusia:Mengelola Waktu. Jakarta : Gramedia. 